\title{
PEMILIHAN GURU SMK BERPRESTASI DENGAN METODE ANALYTICAL NETWORK PROCESS (ANP) DAN KOMPETENSI GOMES
}

\author{
Oleh : \\ Zaeni Miftah \\ Dosen Program Studi Teknik Infomatika \\ STMIK ERESHA \\ Email: \\ Zaenimiftah02@gmail.com
}

\begin{abstract}
The teacher is an educator with a primary task is to educate, teaching, guiding, directing, train, assess and evaluate students. To carry out their duties in a professional manner a teacher not only has the educating ability but also must have a personality that can be relied upon to be a role model for students, families, and communities. Government gives earnest attention to outstanding teachers through Teacher Selection Achievement vocational education either at the unit level, provincial, and national.In this regard, the selection of vocational teachers excels at the unit level vocational education still done manually, which may cause the actual results to be aless objective decision. On this thesis, try the process of selecting the Best Vocational Teachers in the Vocational through a decision support system using Analytical Network Process (ANP) and competence Gomes. This method was chosen because it is able to select the best alternative from a number of alternatives, in this case, meant that alternatives to determine vocational teacher Achievement. Criteria used in the selection process is competency criteria Gomes, which consists of 8 (eight) criteria elaborated into 26 sub-criteria. Results of research aimed at providing advice for vocational in decision making, especially related to the selection of Vocational Teachers Achievement.
\end{abstract}

Keywords:Achievement vocational school teachers, ANP, Competence Gomes 


\begin{abstract}
ABSTRAK
Guru adalah pendidik dengan tugas utama adalah mendidik, mengajar, membimbing, mengarahkan, melatih, menilai dan mengevaluasi peserta didik. Untuk melaksanakan tugasnya secara profesional seorang guru tidak hanya memiliki kemampuan edukatif, tetapi juga harus memiliki kepribadian yang dapat diandalkan sehingga menjadi sosok panutan bagi siswa, keluarga maupun masyarakat.Pemerintah memberikan perhatian yang sungguh-sungguh kepada guru berprestasi melalui Pemilihan Guru SMK Berprestasi baik di tingkat satuan pendidikan, Provinsi, maupun Nasional.Berkaitan dengan hal tersebut, pemilihan guru SMK berprestasi di tingkat satuan pendidikan khususnya di lingkungan SMK masih dilakukan secara manual, yang dapat menyebabkan hasil keputusan menjadi kurang objektif.Pada penelitian ini, dicoba proses pemilihan Guru SMK Terbaik di lingkungan SMK melalui sebuah sistem pendukung keputusan menggunakan metode Analytical Network Process (ANP) dan kompetensi Gomes. Metode ini dipilih karena mampu menyeleksi alternatif terbaik dari sejumlah alternatif, dalam hal ini alternatif yang dimaksudkan yaitu untuk menentukan guru SMK Berprestasi. Kriteria yang digunakan dalam proses seleksi adalah kriteria kompetensi Gomes, yang terdiri dari 8 (delapan) kriteria yang diuraikan menjadi 26 sub kriteria. Hasil penelitian ditujukan untuk memberikan saran bagi SMK dalam pengambilan keputusan khususnya terkait pemilihan Guru SMK Berprestasi.

Kata kunci : Guru SMK Berprestasi, ANP, Kompetensi Gomes
\end{abstract}

\title{
A. PENDAHULUAN
}

Guru SMK Berprestasi merupakan guru SMK model atau contoh bagi guru SMK lainnya, karena yang bersangkutan mempunyai prestasi yang luar biasa atau melebihi yang dicapai guru SMK lain, sehingga berdampak positif bagi perkembangan pendidikan dan peningkatan mutu serta proses hasil pembelajaran. Pemilihan Guru SMK Berprestasi dimaksudkan antara lain untuk mendorong motivasi, dedikasi, loyalitas dan profesionalisme guru (khususnya guru SMK), yang diharapkan akan berpengaruh positif pada kinerja dan prestasi kerjanya pada era globalisasi ini(Kemdikbud, 2013).

Pemilihan guru SMK berprestasi di tingkat satuan pendidikan umumnya belum memiliki suatu Sistem Pendukung Keputusan (Decision Support System).Untuk membantu dalam memilih guru SMK berprestasi dibutuhkan sebuah Sistem Pendukung Keputusan (Decision Support System), diantaranya menggunakan Analytical Network Process (ANP).

Analytical Network Process (ANP) merupakan salah satu metode yang dapat digunakan untuk mengukur bobot kriteria penilaian guru berprestasi dengan melibatkan keterkaitan antar kriteria.Analytical Network Process (ANP) dipandang akan sangat membantu khususnya Kepala Sekolah untuk melakukan penilaian kinerja secara lebih baik dan komprehensif. Adapun Kompetensi Gomes mengandung delapan unsur kompetensi yang sering digunakan untuk penilaian kinerja. Karena dalam penilaian ini yang dinilai adalah kinerja guru, maka Kompetensi Gomes perlu merujuk dan dikombinasikan dengan Pedoman 
Pelaksanaan Penilaian Kinerja Guru yang terdiri dari empat kompetensi, yaitu kompetensi pedagogik, kompetensi sosial, kompetensi profesional, dan kompetensi kepribadian.

Kontribusi yang diberikan pada penelitian ini adalah menyajikan bentuk penerapan metode Analytical Network Process (ANP) dan Kompetensi Gomes sebagai sistem pendukung pengambilan keputusan sehingga dapat dijadikan acuan dan dikembangkan pada penelitian selanjutnya.

\section{B. KAJIAN PUSTAKA}

\section{Pengambilan Keputusan}

Keputusan merupakan hasil pemecahan dalam suatu masalah yang harus dihadapi dengan tegas.Dalam Kamus Besar Ilmu Pengetahuan pengambilan keputusan (Decision Making) didefinisikan sebagai pemilihan keputusan atau kebijakan yang didasarkan atas kriteria tertentu. Proses ini meliputi dua alternatif atau lebih karena seandainya hanya terdapat satu alternatif tidak akanada satu keputusan yang akan diambil(Dagun, 2006).

George R. Terrymenjelaskan dasar-dasar dari pengambilan keputusan yang berlaku, antara lain : intuisi, pengalaman, fakta, wewenang, dan rasional (Syamsi, 2000). Adanya mekanisme yang jelas dan terukur dalam membuat suatu keputusan, memungkinkan untuk dihasilkannya suatu keputusan yang rasional dan lebih obyektif. Namun tidak dapat dipungkiri, bahwa kekuatan intuisi dan pengalaman seseorang juga menjadi dasar yang kuat atas suatu hasil keputusan yang tepat.

\section{Konsep Sistem Pendukung Keputusan}

Konsep sistem pendukung keputusan diperkenalkan pertama kali oleh Michael S. Scoott Morton pada tahun 1970-an dengan istilah Management Decision System. Morton mendefinisikan DSS sebagai "sistem berbasis komputer interaktif, yang membantu para pengambil keputusan untuk menggunakan data dan berbagai model untuk memecahkan masalah-masalah yang tidak terstruktur".(Turban, 2007).

\section{Model Sistem Pendukung Keputusan MCDM/MADM}

MultiKriteria Decision Making (MCDM) adalah disiplinilmu yang bertujuan untuk mendukungpara pengambil keputusanyangdihadapkan denganbanyak kriteria danalternatifsehingga menghasilkan keputusanyang optimal. Tzeng dan Huang (2011:1)mengemukakan bahwa masalah MCDM dapat diklasifikasikan ke dalam dua kategori utamaMultiple Objective Decision Making (MODM) dan Multiple Attribute Decision Making (MADM). MADM menentukan alternatif terbaik dari sekumpulan alternatif (permasalahan pilihan) dengan menggunakan preferensi alternatif sebagai kriteria dalam pemilihan. MODM memakai pendekatan optimasi, sehingga untuk menyelesaikannya harus dicari terlebih dahulu model matematis dari persoalan yang akan dipecahkan. Salah satu metode 
MADM adalah Metode Analytical Network Process (ANP) yang merupakan pengembangan dari metode AHP.

\section{Analytical Network Process (ANP)}

ANP pada dasarnya didesain untuk menangkap secara rasional persepsi orang yang berhubungan sangat erat dengan permasalahan tertentu melalui prosedur yang didesain untuk sampai pada suatu skala preferensi diantara berbagai set alternatif. Analisis ini ditujukan untuk membuat suatu model permasalahan yang tidak mempunyai struktur, biasanya ditetapkan untuk memecahkan masalah yang terukur (kuantitatif), masalah yang memerlukan pendapat (judgement) maupun pada situasi yang kompleks atau tidak terkerangka, pada situasi dimana data, informasi statistik sangat minim atau tidak ada sama sekali dan hanya bersifat kualitatif yang didasari oleh persepsi, pengalaman ataupun intuisi. ANP ini juga banyak digunakan pada keputusan untuk banyak kriteria, perencanaan, alokasi sumberdaya dan penentuan prioritas dari strategi strategi yang dimiliki pemain dalam situasi konflik.

Prinsip kerja ANP adalah pengembangan dari metode AHP dimana kemampuannya dapat mengakomodasi keterkaitan antar kriteria atau alternatifalternatif dalam hal ini keterkaitan dalam satu set elemen (inner dependence) dan keterkaitan antar elemen yang berbeda (outer dependence) sehingga dapat menyelesaikan suatu persoalan kompleks (Saaty, 2008). ANP merupakan teori matematika yang memungkinkan seseorang untuk melakukan hubungan kriteria dan sub kriteria dan memiliki hubungan ketergantungan serta hubungan timbal balik antar elemen.

Beberapa prosedur dalam menyelesaikan persoalan dengan Metode ANP adalah(Saaty, 2008):

a. Penyusunan Struktur Jaringan

Penyusunan jaringan adalah langkah untuk mendefinisikan permasalahan yang kompleks ke dalam kluster dan elemennya, serta identifikasi hubungan interaksi ketergantungan yang ada didalamnya sehingga menjadi lebih jelas dan rinci.

b. Membentuk Matrik Perbandingan

Prinsip ini memberikan penilaian tentang kepentingan relatif dua elemen yang saling mempengaruhi dan adanya timbal balik pada suatu jaringan berdasarkan matriks perbandingan berpasangan.Penilaian ini dapat disajikan dalam bentuk matriks yang disebut matriks pairwisecomparison yaitu matriks perbandingan berpasangan yang memuat tingkat preferensi beberapa alternatif untuk kriteria dengan skala penilaian dari 1 sampai 9 .

Adapun perhitungannya dengan rumus sebagai berikut:

1) Rumus Matrik Perbandingan berpasangan 


$$
A=\left[\begin{array}{ccc}
\frac{w_{1}}{w_{1}} & \frac{w_{1}}{w_{2}} & \cdots \frac{w_{1}}{w_{n}} \\
\frac{w_{2}}{w_{1}} & \frac{w_{2}}{w_{2}} & \cdots \frac{w_{2}}{w_{n}} \\
\vdots & \vdots & \vdots \\
\frac{w_{n}}{w_{1}} & \frac{w_{n}}{w_{2}} & \cdots \frac{w_{n}}{w_{n}}
\end{array}\right]
$$

$\mathrm{A}=a_{i j}$

$a_{i j}=1 / a_{i j}$

2) Menjumlahkan setiap kolom j dalam matriks $A$

$\sum_{j} a_{i j}$

3) Menormalkan setiap kolom j dalam matriks A

$\sum_{i} a_{i j}=1$

Sebut sebagai A'

4) Untuk setiap baris i dalam A', hitung nilai rata-ratanya (eigen vector) :

$w_{i}=\frac{1}{n} \sum_{i} a_{i j}^{\prime}$

Dengan $w_{i}$ adalah bobot tujuan ke-i dari vector bobot

5) Perhitungan Bobot

$(\mathrm{A})\left(\mathrm{W}^{\mathrm{T}}\right)$

Dimana

A : matrik perbandingan berpasangan

$\mathrm{W}^{\mathrm{T}}$ : vektor bobot

6) Menghitung Bobot Elemen

Pada prinsip ini menyajikan matriks pairwise comparison yang kemudian dicari eigen vektornya untuk mendapatkan local priority. Karena matriks pairwise comparison terdapat pada setiap tingkat, maka untuk mendapatkan global priorty dapat dilakukan sintesa diantara local priority. Adapun perhitungannya dengan rumus sebagai berikut:

$\lambda \max =\frac{1}{n} \sum_{i=1}^{n} \quad\left[\frac{\text { elemen } k e_{-i} \text { pada }(A)(W T)}{\text { elemen } k e_{-i} \text { pada } W T}\right]$

\section{Dengan}

A : matrik perbandingan berpasangan

$\mathrm{n}$ : banyaknya elemen

$\lambda$ max : eigen value terbesar dari A

Eigen vektor : bobot prioritas suatu matrik yang kemudian digunakan dalam penyusunan supermatrik.

7) Menghitung Rasio Konsistensi 
Hal ini dapat dicapai dengan mengagresikan seluruh vektor eigen yang diperoleh dari tingkatan hirarki dan selanjutnya diperoleh suatu vektor composite tertimbang yang menghasilkan urutan pengambilan keputusan. Konsistensi logis dilakukan dengan rumus sebagai berikut :

Consistensi Index $(\mathrm{CI})=\frac{\lambda \operatorname{Max}-n}{n-1}$

Consistency Ratio $(\mathrm{CR})=\frac{C I}{R I}$

Jika CI $<0,1$ maka A konsisten

Dimana :

$\mathrm{n} \quad$ : Ukuran matriks $\mathrm{n} \times \mathrm{n}$

RI : Random Indeks

$\lambda$ Max : Eigen Value Maksimum

8) Membuat supermatriks

Yaituuntuk membandingkankriteriadiseluruh sistemberdasarkan hasil matriks perbandingan berpasangan dan dihasilkan nilai eigen vektor kemudian disusun membentuksupermatrixtersebut.

\section{Kompetensi Gomes}

Kinerja merupakan hasil kerja yang dicapai oleh seseorang dalam menjalankan tugas-tugas yang dibebankan kepadanya, yang didasarkan atas kecakapan, pengalaman, kesungguhan serta waktu (Mangkunegara, 2001).Kinerja tenaga pengajar merupakan persoalan yang kompleks, yaitu banyak faktor yang mempunyai kaitan langsung dengan kinerja tersebut.Untuk mengukur kontribusikontribusi tersebut dilakukan dengan melakukan penilaian kinerja.Jadi kinerja dapat diukur dengan instrumen yang dikembangkan dalam studi yang tergabung dalam beberapa ukuran kinerja secara umum, yang kemudian diterjemahkan kedalam penilaian perilaku secara mendasar.

Untuk mampu melahirkan kinerja yang tinggi, maka setiap pekerjaan tersebut memberikan persyaratan kompetensi yang harus dimiliki pekerjaan agar mampu melaksanakan tugas-tugas yang ditanganinya.

Menurut Miller, Rankin and Neathey (2001) dalam Sefudin, dkk (2012), kompetensi didefinisikan sebagai gambaran tentang apa yang yang harus diketahui atau dilakukan seseorang agar dapat melaksanakan pekerjaannya dengan baik. Seseorang yang memiliki kompetensi unggul, akan menunjukkan kinerja yang unggul, dan berprestasi unggul. Kompetensi seseorang akan terlihat dari kinerjanya, sehingga untuk menilai apakah seseorang kompeten maka perlu dilakukan pengukuran terhadap kinerja.

Dalam melakukan penilaian terhadap kinerja yang berdasarkan deskripsi perilaku yang spesifik, maka ada beberapa dimensi atau kriteria yang perlu mendapat perhatian yang dikenal dengan istilah Kompetensi Gomes, yaitu:

1. Quantity of work, yaitu jumlah kerja yang dilakukan dalam suatu periode waktu yang ditentukan.

2. Quality of work, yaitu kualitas kerja berdasarkan syarat-syarat kesesuaian dan kesiapannya. 
3. Job Knowledge, yaitu luasnya pengetahuan tentang pekerjaan yang dikerjakan dan keterampilannya.

4. Creativeness, yaitu kreativitas yang berkembang.

5. Cooperation, yaitu kesediaan untuk bekerjasama dalam melakukan pekerjaan dilingkungan pekerjaan.

6. Defendability, yaitu kesadaran dan dapat dipercaya dalam hal kehadiran atau penyelelesaian kerja.

7. Initiative, yaitu semangat untuk melaksanakan tugas-tugas baru dan memperbesar tanggung jawab.

8. Personal qualities, yaitu menyangkut kepribadian, kepemimpinan, keramahtamahan dan integritas pribadi.

(Atikah, dkk, 2014:466-467).

\section{METODE PENELITIAN}

\section{Tahapan-tahapan Penelitian}

Tahap-tahapan dan kerangka pikir yang digunakan adalah sebagai berikut:

Tahap pertama menganalisa permasalahan yang terjadi pada sistem pemilihan Guru SMK Berprestasi dan menetapkan beberapa permasalahan tersebut untuk dianalisa dan dicarikan solusi pemecahan masalahnya.

Tahap kedua adalah menentukan ruang lingkup dari masalah yang akan dibahassehingga lebihfokus ke pokok permasalahannya.

Tahap ketiga adalah melakukan wawancara dengan Kepala Sekolah untuk mendapatkan informasi mengenai masalah yang sedang dihadapi.

Tahap Keempat melakukan studi dokumentasi dengan mengumpulkan dokumen yang dibutuhkan melalui bagian Tata Usaha. Selanjutnya, studi literatur dengan mencari sumber melalui buku, jurnal, dan website di internet. Informasiinformasi yang berhasil dikumpulkan dijadikan landasan teoritis dalam penyusunan penelitian ini agar dapat dipertanggung jawabkan secara ilmiah.

Tahap kelima menyebarkan kuesioner kepada para responden ahli. Untuk menentukan responden menggunakan teknik purposive sampling. Purposivesampling merupakan teknik sampling yang tidak memberikan kesempatan yang sama bagi setiap anggota populasi, sampel sumber datanya adalah orang yang ahli (Sugiyono, 2010).

Tahap keenam membuat desain sistem pemilihan Guru SMK Berprestasi dengan pendekatan Sistem Pendukung Keputusan melalui metode Analytical Network Process (ANP) dan kompetensi Gomes dengan menggunakan 8 kriteria, 26 sub kriteria dan 6 alternatif.

\section{HASIL DAN PEMBAHASAN}

\section{Desain metode Analytical Network Process (ANP) dan Kompetensi Gomes}

1) Analisis Kriteria

Kriteria dan sub kriteria pemilihan guru SMK berprestasi disesuaikan dengan klasifikasi yang ada pada Pedoman Pemilihan Guru SMK Berprestasi Tingkat Nasional yang dikeluarkan oleh Kementerian Pendidikan dan 
Kebudayaan Direktorat Jenderal Pendidikan Menengah Direktorat Pendidik dan Tenaga Kependidikan Pendidikan Menengah Tahun 2013. Klasifikasi ini kemudian dikembangkan dengan Teori Kompetensi Gomes sehingga menghasilkan 8 (delapan) kriteria.Delapan kriteria ini dikenal dengan istilah "Kompetensi Gomes".

Adapun kriteria dan subkriteria dijabarkan sebagaimana mana berikut:

Kriteria 1 : Quantity of work, yaitu jumlah kerja yang dilakukan dalam suatu periode waktu yang ditentukan.

Sub kriteria $1:$ Jumlah jam mengajar

Sub kriteria 2 : Beban kerja lainnya selain tugas mengajar

Sub kriteria 3 : Jumlah mata pelajaran yang diampu

Kriteria 2 :Quality of work, yaitu kualitas kerja berdasarkan syarat-syarat kesesuaian dan kesiapannya.

Sub kriteria 1 : Membuat Rencana Program Pembelajaran

Sub kriteria 2 : Kesesuaian materi pembelajaran dengan kurikulum

Sub kriteria 3 : Melakukan evaluasi pembelajaran

Kriteria 3 :Job Knowledge, yaitu luasnya pengetahuan tentang pekerjaan yang dikerjakan dan keterampilannya.

Sub kriteria 1 : Pengetahuan mengenai tugas

Sub kriteria 2 : Kemauan untuk terus belajar

Sub kriteria 3 : Memiliki keterampilan sesuai bidang keahlian

Kriteria 4 :Creativeness, yaitu kreativitas yang

berkembang.

Sub kriteria 1 : Keaslian gagasan-gasan yang dimunculkan

Sub kriteria 2 : Tindakan untuk menyelesaikan persoalan-persoalan yang timbul

Sub kriteria 3 : Prestasi yang dihasilkan baik prestasi guru maupun pembimbingan terhadap siswa

Kriteria 5 :Cooperation, yaitu kesediaan untuk bekerjasama dalam melakukan pekerjaan dilingkungan pekerjaan.

Sub kriteria 1: Kesetiaan dan loyalitas pada lembaga

Sub kriteria 2 : Kemauan untuk bekerja sama dengan rekan guru

Sub kriteria 3 : Interaksi dengan siswa

Kriteria 6 : Defendability, yaitu kesadaran dan dapat dipercaya dalam hal kehadiran atau penyelelesaian kerja.

Sub kriteria 1 : Ketepatan waktu dalam menyelesaikan tugas

Sub kriteria 2 : Mengisi absen harian

Sub kriteria 3 : Mengisi agenda mengajar

Kriteria 7 :Initiative, yaitu semangat untuk melaksanakan tugas-tugas baru dan memperbesar tanggung jawab.

Sub kriteria 1 : Semangat untuk memperbesar tanggung jawab

Sub kriteria 2 : Semangat dalam melaksanakan tugas-tugas baru

Sub kriteria 3 : Memotivasi siswa

Kriteria 8 :Personal qualities, yaitu menyangkut kepribadian, kepemimpinan, keramahtamahan dan integritas pribadi.

Sub kriteria 1 : Keteladanan

Sub kriteria 2 : Integritas pribadi 
Sub kriteria 3 : Gaya dan penampilan mengajar

Sub kriteria 4 : Memotivasi Siswa

Sub kriteria 5 : Interaksi dengan siswa

\section{2) Analisis Alternatif}

Alternatif akandiseleksi dari kalangan guru yang memenuhi syarat administrasi guru SMK Berprestasi yang sudah ditetapkan oleh SMK Yadika 13 Tambun Bekasi, seperti : berstatus guru tetap yayasan, masa kerja 7 (tujuh) tahun, masih aktif mengajar, beban mengajar minimal 24 jam perminggu, dan tidak sedang menjabat sebagai Kepala Sekolah atau Wakil Kepala Sekolah. Hanya guru yang memenuhi semua syarat yang akan dijadikan alternatif dalam penelitian ini.

Untuk mendapatkan data yang sesuai dengan kriteria tersebut. Maka teknik yang digunakan adalah dengan menggunakan kuesioner. Kuesioner dibagikan kepada responden ahli yang terdiri dari unsur pimpinan, yaitu Kepala Sekolah, Wakil Kepala Sekolah Bidang Kurikulum, Wakil Kepala Sekolah bidang Kesiswaan dan perwakilan dari siswa dalam hal ini Ketua OSIS.

Kuesioner akan dibuat berdasarkan cluster tertentu, setiap responden ahli akan mengisi kuesioner dengan cluster berbeda. Adapun pemetaan kuesioner sebagaimana disajikan pada Tabel 1 .

Tabel 1.

Kriteria, Sub Kriteria, dan Responden Ahli

\begin{tabular}{|c|c|c|c|}
\hline No & Kriteria & Sub Kriteria & Responden Ahli \\
\hline 1 & Cooperation & $\begin{array}{l}\text { Kesetiaan dan loyalitas pada lembaga } \\
\text { Kemauan untuk bekerjasama dengan } \\
\text { rekan guru } \\
\text { Interaksi dengan siswa }\end{array}$ & Kepala Sekolah \\
\hline 2 & Defendability & $\begin{array}{l}\text { Ketepatan waktu menyelesaikan tugas } \\
\text { Mengisi absen harian } \\
\text { Mengisi agenda mengajar }\end{array}$ & \\
\hline 3 & Initiative & $\begin{array}{l}\text { Semangat memperbesar tanggung } \\
\text { jawab } \\
\text { Semangat dalam menjalankan tugas } \\
\text { baru } \\
\text { Memotivasi siswa }\end{array}$ & $\begin{array}{l}\text { Wakil Kepala Sekolah } \\
\text { Bidang Kurikulum }\end{array}$ \\
\hline 4 & Quantity of Work & $\begin{array}{l}\text { Jumlah jam mengajar } \\
\text { Beban kerja lainnya selain tugas } \\
\text { mengajar } \\
\text { Jumlah mata pelajaran yang diampu }\end{array}$ & \\
\hline 5 & Quality of Work & $\begin{array}{l}\text { Kesiapan terhadap KBM } \\
\text { Kesesuaian materi dengan kurikulum } \\
\text { Melakukan evaluasi }\end{array}$ & \\
\hline 6 & Job Knowledge & $\begin{array}{l}\text { Pengetahuan mengenai tugas } \\
\text { Kemauan untuk terus belajar } \\
\text { Memiliki keterampilan sesuai bidang } \\
\text { keahlian }\end{array}$ & $\begin{array}{l}\text { Wakil Kepala Sekolah } \\
\text { Bidang Kesiswaan }\end{array}$ \\
\hline 7 & Creativeness & $\begin{array}{l}\text { Keaslian gagasan } \\
\text { Tindakan untuk menyelesaikan } \\
\text { persoalan yang timbul }\end{array}$ & \\
\hline
\end{tabular}


$8 \quad$ Personal Qualities

Prestasi yang dihasilkan

Keteladanan

Integritas pribadi

Gaya dan penampilan mengajar

Memotivasi Siswa

Interaksi dengan Siswa

3) Teknik Analisis

Penjabaran dari teknik analisis menggunakan metode Analytical Network Process (ANP) adalah sebagai berikut :

a. Mengatur control jaringan untuk masing-masing Kriteria dan alternatif.

b. Menentukan bobot pada masing-masing kriteria, sub kriteria dan alternative berdasarkan kuesioner yang disebar pada masing-masing responden Ahli

Perhitungan bobot untuk kriteria dan alternate sebagaimana dalam matriks perbandingan berikut :

Tabel 2.

Matriks Faktor Pembobotan untuk Kriteria Initiative

\begin{tabular}{lccc}
\hline & IB1 & IB2 & IB3 \\
\hline IB1- Memotivasi Siswa & 1 & $1 / 5$ & $1 / 3$ \\
$\begin{array}{l}\text { IB2- Semangat dalam } \\
\text { menjalankan tugas baru }\end{array}$ & 5 & 1 & 4 \\
$\begin{array}{l}\text { IB3- Semangat memperbesar } \\
\text { tanggung jawab }\end{array}$ & 3 & $1 / 4$ & 1 \\
\hline
\end{tabular}

Tabel 3.

Matriks Faktor Pembobotan untuk Kriteria Initiative yang Disederhanakan

\begin{tabular}{lccc}
\hline & IB1 & IB2 & IB3 \\
\hline $\begin{array}{l}\text { IB1- Memotivasi } \\
\text { Siswa }\end{array}$ & 1.0000 & 0.2000 & 0.3333 \\
$\begin{array}{l}\text { IB2- Semangat dalam } \\
\text { menjalankan tugas } \\
\text { baru }\end{array}$ & 5.0000 & 1.0000 & 4.0000 \\
$\begin{array}{l}\text { IB3- Semangat } \\
\text { memperbesar } \\
\text { tanggung jawab }\end{array}$ & 3.0000 & 0.2500 & 1.0000 \\
$\quad \sum$ & 9.0000 & 1.4500 & 5.3333 \\
\hline
\end{tabular}

Dari elemen pada masing-masing kolom dibagi dengan hasil penjumlahan pada masing-masing kolom yang bersangkutan, maka diperoleh bobot relatif yang dinormalkan.Nilai eigen vektor dihasilkan dengan membagi bobot relatif dengan jumlah ukuran matriks pada masing-masing baris. Hasilnya seperti pada tabel berikut : 
Tabel 4.

Matriks Faktor Pembobotan untuk Kriteria Initiative yang Dinormalkan

\begin{tabular}{lcccc}
\hline & IB1 & IB2 & IB3 & $\begin{array}{c}\text { Eigen } \\
\text { Vektor }\end{array}$ \\
\hline $\begin{array}{l}\text { IB1- } \\
\text { Memotivasi }\end{array}$ & 0.1111 & 0.1379 & 0.0625 & 0.1038 \\
$\begin{array}{l}\text { Siswa } \\
\text { IB2- Semangat }\end{array}$ & 0.5556 & 0.6897 & 0.7500 & 0.6651 \\
dalam \\
$\begin{array}{l}\text { menjalankan } \\
\text { tugas baru }\end{array}$ & & & & \\
$\begin{array}{l}\text { IB3- Semangat } \\
\text { memperbesar } \\
\text { tanggung jawab }\end{array}$ & 0.3333 & 0.1724 & 0.1875 & 0.2311 \\
\hline
\end{tabular}

Menentukan bobot local priority $\left(\mathrm{A} . \mathrm{W}^{\mathrm{T}}\right)$

IB1 $=(1.000 * 0.1038)+(0.2000 * 06651)+(0.3333 * 0.2311)=0.3139$

IB2 $=(5.000 * 0.1038)+(1.0000 * 06651)+(4.0000 * 0.2311)=2.1086$

IB3 $=(3.000 * 0.1038)+(0.2500 * 06651)+(1.0000 * 0.2311)=0.7089$

Selanjutnya menentukan nilai eigen maksimum $\left(\lambda_{\text {maks }}\right)$ didapat dengan menjumlahkan hasil pembagian local priority dengan eigen vektor kemudian dibagi dengan ukuran matriks, nilai eigen maksimum adalah :

$\lambda_{\text {maksimum }}=((0.3139 / 0.1038)+(2.1086 / 0.6651)+(0.7089 / 0.2311)) / 3$ $=3.0869$

Menentukan nilai Indeks konsistensi, karena matriks berordo 3 ( yakni terdiri dari 3 kriteria) maka nilai indeks konsistensi yang diperoleh adalah :

$$
\mathrm{CI}=\frac{\lambda \text { maksimum }-\mathrm{n}}{n-1}=\frac{3.0869-3}{3-1}=0.0435
$$

Menentukan Konsistensi Rasio, karena $\mathrm{n}=3$ maka RI = 0,58 (tabel Saaty), maka :

$\mathrm{CR}=\frac{C I}{R I}=\frac{0.0435}{0,58}=0.0750$

Karena $\mathrm{CR}<0,1$ maka preferensi responden adalah konsisten

Adapun perhitungan bobot pada kriteria quantity of work seperti Tabel 3.5 berikut:

Tabel 5.

Matriks Faktor Pembobotan untuk Kriteria Quantity of Work

\begin{tabular}{lccc}
\hline & QtB1 & QtB2 & QtB3 \\
\hline $\begin{array}{l}\text { QtB1-Beban kerja lainnya } \\
\text { selain tugas Mengajar }\end{array}$ & 1 & 2 & 4 \\
$\begin{array}{l}\text { QtB2-Jumlah jam } \\
\text { mengajar }\end{array}$ & $1 / 2$ & 1 & 3 \\
$\begin{array}{l}\text { QtB3-Jumlah mata } \\
\text { pelajaran diampu }\end{array}$ & $1 / 4$ & $1 / 3$ & 1 \\
\hline
\end{tabular}




\begin{tabular}{lccc}
\hline & QtB1 & QtB2 & QtB3 \\
\hline $\begin{array}{l}\text { QtB1-Beban kerja } \\
\text { lainnya selain tugas } \\
\text { Mengajar }\end{array}$ & 1.0000 & 2.0000 & 4.0000 \\
$\begin{array}{l}\text { QtB2-Jumlah jam } \\
\text { mengajar }\end{array}$ & 0.5000 & 1.0000 & 3.0000 \\
$\begin{array}{l}\text { QtB3-Jumlah mata } \\
\text { pelajaran diampu } \\
\qquad\end{array}$ & 0.2500 & 0.3333 & 1.0000 \\
\multicolumn{1}{c}{} & 1.7500 & 3.3333 & 8.0000 \\
\hline
\end{tabular}

Dari elemen pada masing-masing kolom dibagi dengan hasil penjumlahan pada masing-masing kolom yang bersangkutan, maka diperoleh bobot relative yang dinormalkan.nilai eigen vektor dihasilkan dengan membagi bobot relative dengan jumlah ukuran matriks pada masing-masing baris. Hasilnya seperti pada tabel berikut :

Tabel 6.

Matriks Faktor pembobotan untuk Kriteria Quantity of Work yang Dinormalkan

\begin{tabular}{lcccc}
\hline & QtB1 & QtB2 & QtB3 & $\begin{array}{c}\text { Eigen } \\
\text { Voktor }\end{array}$ \\
\hline $\begin{array}{l}\text { QtB1-Beban } \\
\text { kerja lainnya } \\
\text { selain tugas }\end{array}$ & 0.5714 & 0.6000 & 0.5000 & 0.5571 \\
$\begin{array}{l}\text { Mengajar } \\
\text { QtB2-Jumlah }\end{array}$ & 0.2857 & 0.3000 & 0.3750 & 0.3202 \\
jam mengajar & & & & \\
$\begin{array}{l}\text { QtB3-Jumlah } \\
\text { mata pelajaran } \\
\text { diampu }\end{array}$ & 0.1429 & 0.1000 & 0.1250 & 0.1226 \\
\hline
\end{tabular}

Menentukan bobot local priority $\left(\mathrm{A} . \mathrm{W}^{\mathrm{T}}\right)$

$\mathrm{QtB} 1=(1.000 * 0.5571)+(2.000 * 0.3202)+(4.0000 * 0.1226)=1.6881$

$\mathrm{QtB} 2=(0.500 * 0.5571)+(1.000 * 0.3202)+(3.0000 * 0.1226)=0.9667$

$\mathrm{QtB} 3=(0.2500 * 0.5571)+(0.3333 * 0.3202)+(1.0000 * 0.1226)=0.3687$

Selanjutnya menentukan nilai eigen maksimum $\left(\lambda_{\text {maks }}\right)$ didapat dengan menjumlahkan hasil pembagian local priority dengan eigen vektor kemudian dibagi dengan ukuran matriks, nilai eigen maksimum adalah :

$\lambda_{\text {maksimum }}=((1.6881 * 0.5571)+(0.9667 * 0.3202)+(0.3687 * 0.1226)) / 3$

$=3.0183$

Menentukan nilai Indeks konsistensi, karena matriks berordo 3 ( yakni terdiri dari 3 kriteria) maka nilai indeks konsistensi yang diperoleh adalah :

$$
\mathrm{CI}=\frac{\lambda \text { maksimum }-\mathrm{n}}{n-1}=\frac{3.0183-3}{3-1}=0.0092
$$

Menentukan Konsistensi Rasio, karena $\mathrm{n}=3$ maka RI = 0,58 (tabel Saaty), maka :

$$
\mathrm{CR}=\frac{C I}{R I}=\frac{0.0092}{0,58}=0.0158
$$

Karena $\mathrm{CR}<0,1$ maka preferensi responden adalah konsisten 


\section{Pengolahan Data untuk Kriteria}

Kuesioner yang diolah berdasarkan masing-masing cluster yang telah dibagikan kepada responden ahli, hasil penilaian kuesioner berpedoman pada skala perbandingan kepentingan (Saaty, 2008) yang diinputkan secara manual dan menggunakan softwaresuperdecision, seperti berikut:

a. Hasil Kuesioner dari Responden Kepala Sekolah

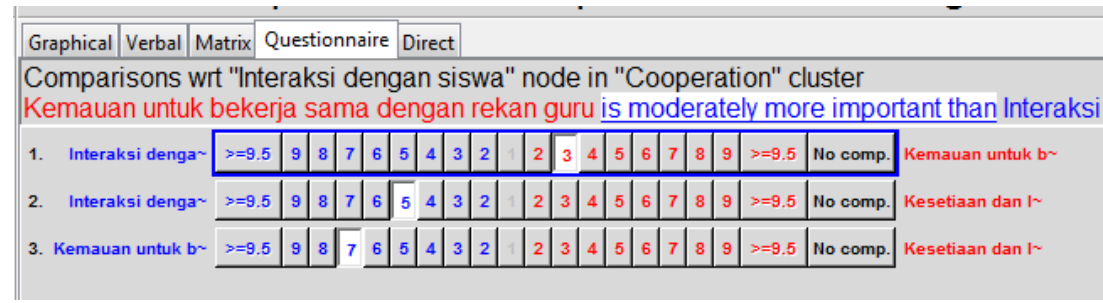

Gambar 1.

Input Manual Kedalam SuperDecision

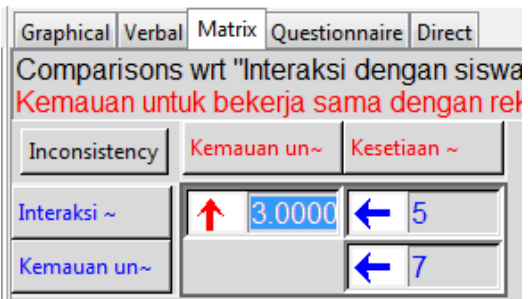

Gambar 2.

Matrik Perbandingan Berpasangan

\begin{tabular}{|c|c|}
\hline \multicolumn{2}{|c|}{ Inconsistency: 0.06239} \\
\hline Interaksi & 0.27895 \\
\hline Kemauan u & 0.64912 \\
\hline Kesetiaan & 0.07193 \\
\hline
\end{tabular}

Gambar 3.

Hasil Inkonsisten dari Perbandingan Berpasangan 
b. Hasil Kuesioner dari Responden Wakasek Kurikulum

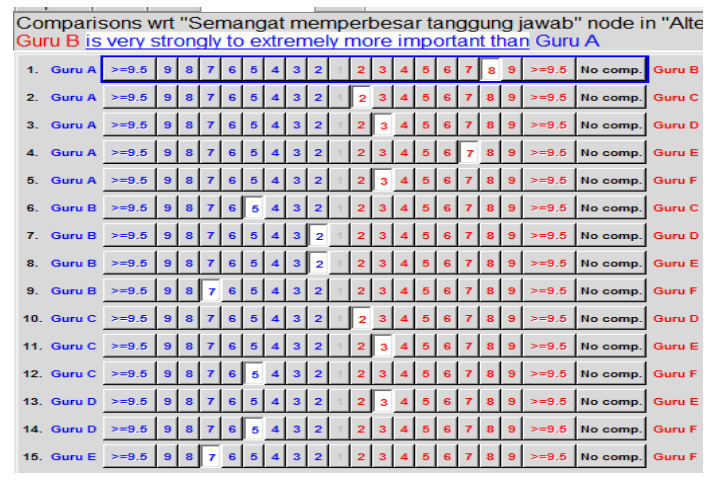

Gambar 4.

Input Manual kedalam SuperDecision

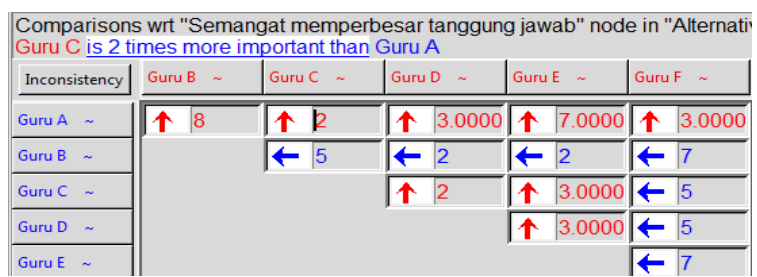

Gambar 5.

Matrik Perbandingan Berpasangan

\begin{tabular}{||l|l|l||}
\hline \multicolumn{2}{||c|}{ Inconsistency: 0.07116} \\
\hline Guru A & & 0.03782 \\
\hline Guru B & & 0.37248 \\
\hline Guru C & & 0.10283 \\
\hline Guru D & & 0.15393 \\
\hline Guru E & & 0.28541 \\
\hline Guru F & 0.04753 \\
\hline
\end{tabular}

Gambar 6.

Hasil Inkonsisten dari Perbandingan Berpasangan

c. Hasil Kuesioner dari Responden Wakasek Kesiswaan

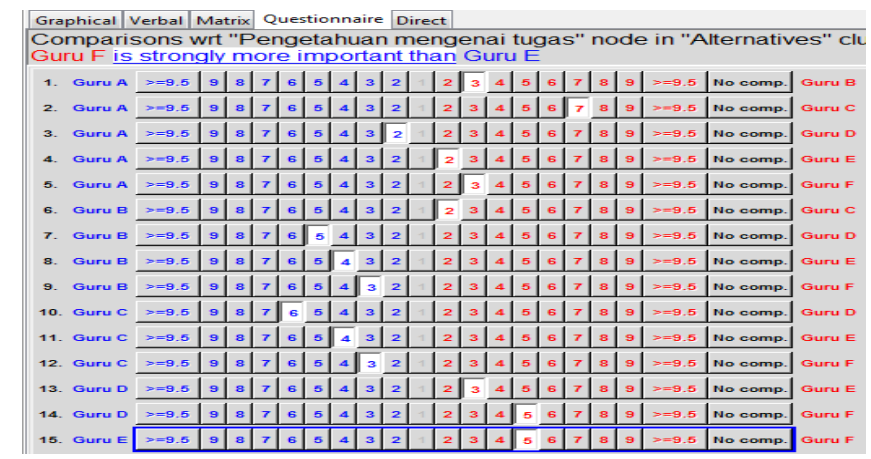

Gambar 7.

Input Manual kedalam SuperDecision 


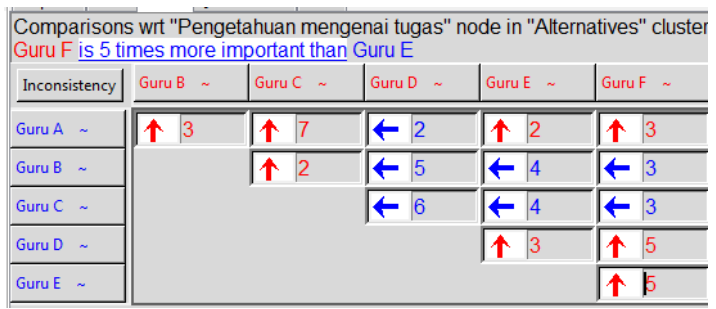

Gambar 8.

Matrik Perbandingan Berpasangan

\begin{tabular}{|l|l|l|}
\hline \multicolumn{2}{|c}{ Inconsistency: 0.06398} \\
\hline Guru A & & 0.05913 \\
\hline Guru B & & 0.26355 \\
\hline Guru C & & 0.37718 \\
\hline Guru D & & 0.03854 \\
\hline Guru E & & 0.07971 \\
\hline Guru F & & 0.18189 \\
\hline
\end{tabular}

Gambar 9.

Hasil Inkonsisten dari Perbandingan Berpasangan

d. Hasil Kuesioner dari Responden Ketua OSIS

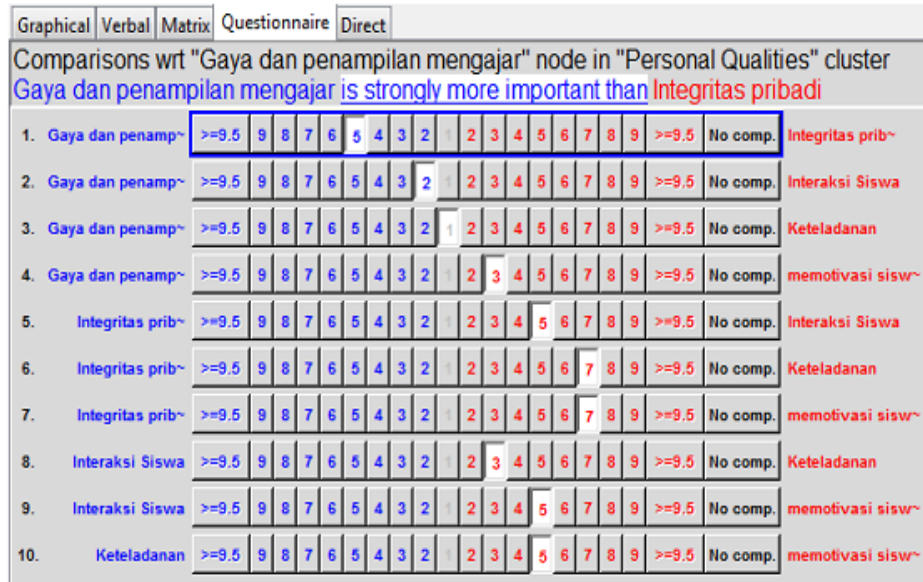

Gambar 10.

Input Manual kedalam SuperDecision

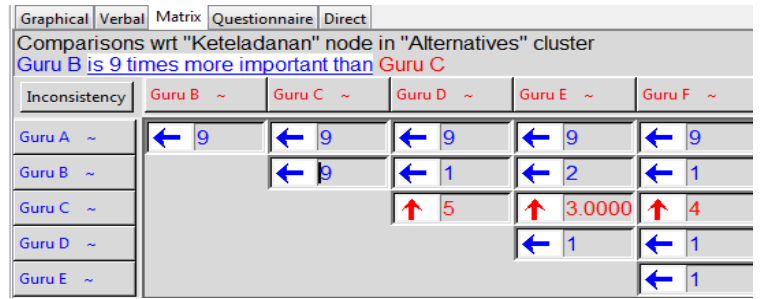

Gambar 11.

Matrik Perbandingan Berpasangan 


\begin{tabular}{|l|l|l|}
\hline \multicolumn{2}{|c|}{ Inconsistency: 0.06601} \\
\hline Guru A & & 0.62446 \\
\hline Guru B & & 0.11294 \\
\hline Guru C & & 0.02632 \\
\hline Guru D & & 0.08580 \\
\hline Guru E & & 0.06879 \\
\hline Guru F & & 0.08170 \\
\hline
\end{tabular}

Gambar 12.

Hasil Inkonsisten dari Perbandingan Berpasangan

\section{e. Unweighted Super Matrix}

Unweighted super matrix merupakan eigenvector-eigen vector kolom yang diperoleh dari matrix perbandingan berpasangan dari elemen-elemen seperti pada gambar berikut

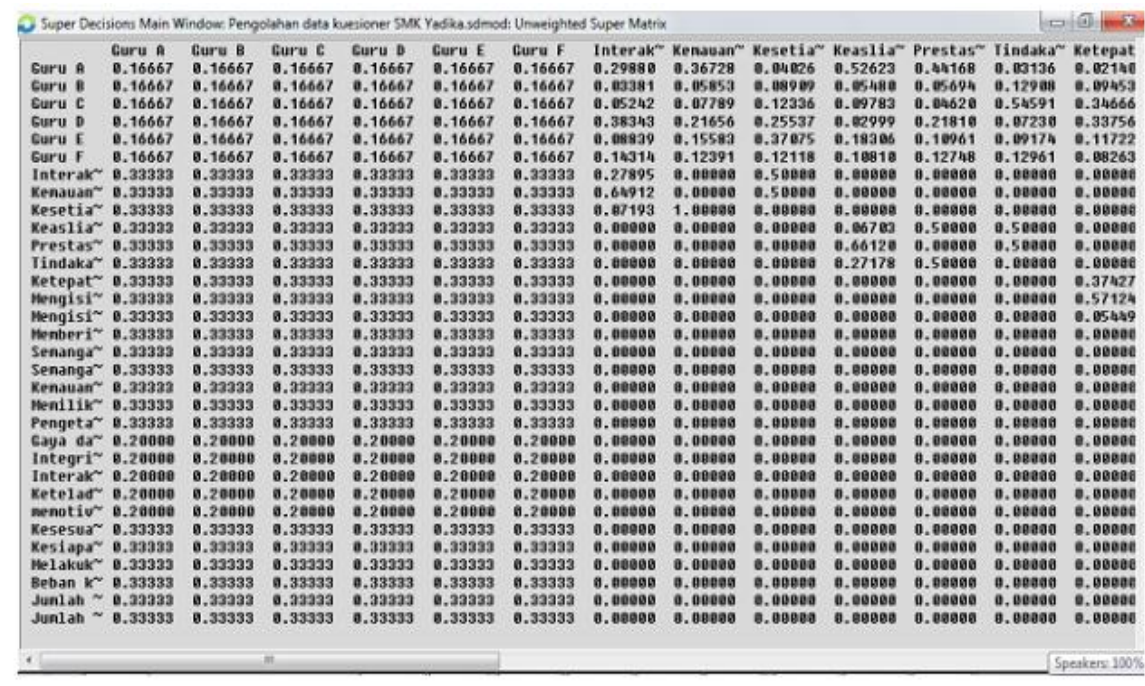

Gambar 13.

\section{Unweighted Super Matrix}

\section{f. Limit Super Matrix}

Limit super matrix diperoleh dengan mengalikan antar kriteria dan bobot alternative untuk memperoleh hasil akhir, hasilnya seperti gambar dibawah :

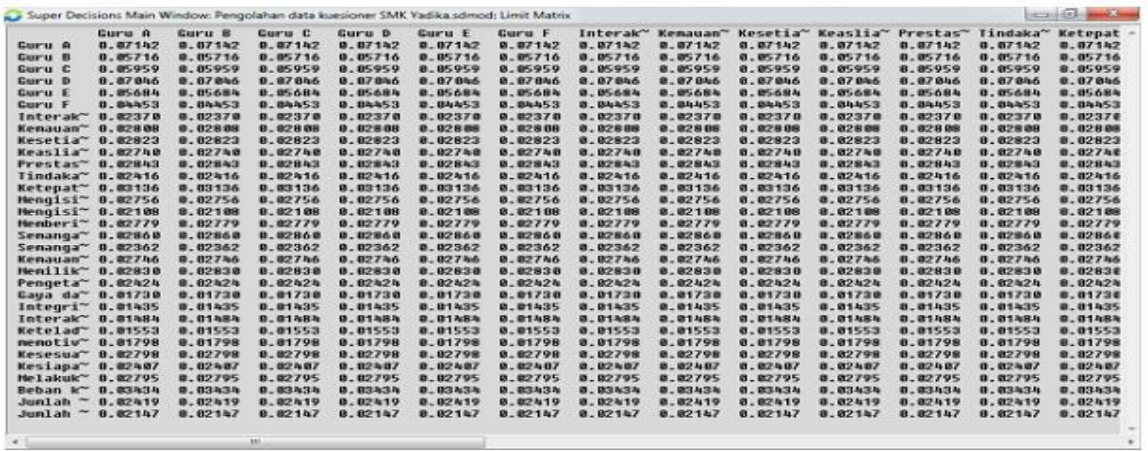

Gambar 14.

Hasil Limit Supermatrix Pemilihan Guru SMK Berprestasi 


\section{g. Analisis Sensitivitas}

Dari hasil pengolahan data berdasarkan tabel kriteria dan alternative yang telah ditentukan maka hasil pengolahan menggunakan super decision dapat ditunjukan dengan synthesisberikut :

N New synthesis for: Super Decisions Main Window: Pengolahan data...
\begin{tabular}{|l|l|l|l|l|}
\hline \hline $\begin{array}{l}\text { Here are the overall synthesized priorities for the } \\
\text { alternatives. You synthesized from the network Super } \\
\text { Decisions Main Window: Pengolahan data kuesioner SMK } \\
\text { Yadika.sdmod }\end{array}$ \\
\hline \hline \multicolumn{1}{|c|}{ Name } & Graphic & \multicolumn{1}{|c|}{ Ideals } & Normals & Raw \\
\hline \hline Guru A & & 1.000000 & 0.198382 & 0.071418 \\
\hline \hline Guru B & & 0.800423 & 0.158790 & 0.057164 \\
\hline \hline Guru C & & 0.834393 & 0.165529 & 0.059590 \\
\hline \hline Guru D & & 0.986643 & 0.195732 & 0.070464 \\
\hline \hline Guru E & & 0.795863 & 0.157885 & 0.056839 \\
\hline \hline Guru F & & 0.623457 & 0.123683 & 0.044526 \\
\hline
\end{tabular}

\section{Gambar 15.}

\section{Hasil Synthesis Pemilihan Guru SMK Berprestasi}

Berdasarkan hasil olahan data kriteria dan alternative yang telah ditentukan, dapat diketahui bahwa guru A memiliki rangking (nilai) tertinggi diantara alternative yang telah ditentukan.

Hasil prioritas diatas didasarkan dari hasil olahan menggunakan Software Super Decision, diperoleh nilai konsistensi $<=0.1$ dapat diartikan bahwa data dalam menentukan guru SMK Berprestasi tingkat kesalahannya sebesar 0.1 dan tingkat kebenaranya mendekati 0.9 (konsisten), sehingga tingkat validitas dan keakuratan data mencapai $90 \%$ dan dapat diterima.

\section{E. SIMPULAN}

Untuk menentukan Guru SMK Berprestasi di tingkat satuan pendidikan Sekolah Menengah Kejuruan dengan menggunakan metode Analytical Network Process (ANP) dan kompetensi Gomes dibutuhkan 8 kriteria yang diurai menjadi 26 subkriteria. Adapun 8 kriteria tersebut adalah Quantity of work, Quality of work,Job Knowledge, Creativeness, Cooperation, Defendability, Initiative, dan Personal Qualities. Sedangkan jumlah alternatif yang didapatkan berdasarkan persyaratan Guru SMK Berprestasi sebanyak 6 alternatif guru-guru yang telah memenuhi persyaratan tersebut.Angket dibagikan kepada para responden ahli meliputi unsur Kepala Sekolah, Wakasek Kurikulum, Wakasek Kesiswaan dan Ketua OSIS.

Dengan diterapkan metode Analytical Network Process (ANP) dan Kompetensi Gomes dalam menentukan guru SMK Berprestasi, proses penentuan menjadi lebih cepat, tepat dan akurat sehingga hasilnya lebih efisien dan optimal.Selain itu dalam penentuan Guru SMK Berprestasi di tingkat satuan pendidikan menjadi lebih objektif karena didukung adanya uji konsistensi menggunakan Sotfware Super Decision dalam penentuan bobot nilai. 
Hasil yang diperoleh berdasarkan bobot penilaian menggunakan Software Super Decision diperoleh nilai konsistensi $<=0,1$ dapat diartikan bahwa data sudah dianggap benar (konsisten) dan untuk penentuan guru SMK Berprestasi ini mengandung tingkat kebenarannya mendekati $90 \%$ sehingga tingkat validitas dan keakuratan data dapat diterima. Adapun penentuan nilai rasio konsistensi tergantung kepada kriteria dan alternatif yang telah ditentukan.

\section{DAFTAR PUSTAKA}

Atikah, dkk. (2014).Perancangan Penilaian Kinerja guru Berdasarkan standar Kualifikasi Akademik Kompetensi Guru dan Kompetensi Gomes sebagai Acuan Pemberian Insentif (Studi Kasus SMA Brawijaya Smart School, Malang). Jurusan Teknik Industri, Fakultas Teknik, Universitas Brawijaya.

Dagun, M. Save. (2006). Kamus Besar Ilmu Pengetahuan.Jakarta : Lembaga Pengkajian Kebudayaan Nusantara (LPKN).

Kementerian Pendidikan dan Kebudayaan Direktorat Jenderal Pendidikan Menengah Direktorat Pendidik dan Tenaga Kependidikan Pendidikan Menengah.(2013). Pedoman Pemilihan Guru SMK Berprestasi di Tingkat Nasional.

Mangkunegara, Anwar Prabu.(2001).Manajemen Sumber Daya Manusia.Perusahaan.Bandung: Remaja Rosdakarya.

Saaty, Thomas L. (2008). The analytic Hierarchy and Analytic Network Measurement Processes: Application to Decision under Risk.European Journal of Pure and Applied Mathematics. Vol 1 No 12008 (122-196). ISSN 1307-5543.

Sugiyono. (2010). Metode Penelitian Pendidikan Pendekatan Kuantitatif, Kualitatif, dan $R \& D$. Bandung:Alfabeta.

Sefudin, A, Gayatri, AM, Hapsari, S. (2012). Manajemen Sumber Daya Manusia. Jakarta: Unindra Press.

Syamsi, Ibnu. (2000). Pengambilan keputusan dan Sistem Informasi .Jakarta :Bumi Aksara.

Turban,Efraim, Jay E. Aronson, Ting-Peng Liang.(2007).Decision Support Systems and Intelligent Systems, Edisi 7 Prentice Hall.

Tzeng,Gwo-Shiung, Jih-Jeng Huang.(2011), Multiple Attribute Decision Making Methods and applications.CRC Press. 